\title{
Heavy Metal Content in Terraced Rice Fields at Sruwen Tengaran Semarang - Indonesia
}

\author{
Yulis Hindarwati ${ }^{1, *}$, Tri Retnaningsih Soeprobowati ${ }^{2}$, Sudarno $^{3}$ \\ ${ }^{1}$ Master Program of Environmental Science, School of Postgraduate Studies, Diponegoro University, Semarang - Indonesia \\ ${ }^{2}$ Departement of Enviromental Engineering, Faculty of Engineering, Diponegoro University, Semarang - Indonesia \\ ${ }^{3}$ Departement of Biology, Faculty Science and Mathematics, Diponegoro University, Semarang - Indonesia
}

\begin{abstract}
The presence of heavy metal on agricultural soils can be caused not only natural factors but also due to human intervention. Differences in management and lack of understanding of farmers in the production input of fertilizers and pesticides ensued in land ravaged. Periodic testing of paddy fields is necessary to minimize the contaminants from being absorbed by plants that will have an impact on health decline. The purpose of the assessment was to identify the heavy metal content in the terraced rice field in Sruwen Village, Tengaran District, Semarang Regency. Survey was conducted in February 2017. Sampling on terraced rice fields of different heights consisted of upper, middle, and upper down. Taken as many as eight single points and composed at a depth of $0-20 \mathrm{~cm}$ and $20-40 \mathrm{~cm}$. The identification results showed that heavy metal content of $\mathrm{Pb}, \mathrm{Cd}$, and $\mathrm{Cu}$ were present at all altitudes. Heavy Metals $\mathrm{Pb}$ and $\mathrm{Cd}$ at a depth of $0-20 \mathrm{~cm}$ were higher from $20-40 \mathrm{~cm}$ in the upper and lower rice fields but lower in the middle rice field. $\mathrm{Cu}$ heavy metal at a depth of $0-20 \mathrm{~cm}$ was higher than $20-40 \mathrm{~cm}$ in all altitude land. The heavy metal content of $\mathrm{Pb}, \mathrm{Cd}$, and $\mathrm{Cu}$ was still below the heavy metal standard set by the European Union and India.
\end{abstract}

\section{Introduction}

The demand for increased productivity as an effort to fulfill food needs is very much affecting the farmers. To increase production with excess input in the form of fertilizers and chemical pesticides basically accelerate the process of environmental degradation. The impact caused by environmental pollution is the chemical residue in the soil of heavy metal. The presence of natural content of heavy metals in agricultural soils can derived from soil parent material and when it accumulates causing impaired soil function and affect plant growth [1].

The lack of understanding of farmers on environmental sustainability and inherited practices is a difficult social factor to tackle. The experience of farmers shows that the success of agricultural production still depends on the use of excess fertilizers and pesticides. This is triggered by the difficulty of receiving technological innovation. Differences in wetland management have different effects from both nutrient content and heavy metal contamination. Other factors can also be caused by natural factors, proximity to roads, and water sources. Excessive and fertilized irrigation water, especially the direct use of fertilizers and pesticides in agricultural activities will seep into the soil and contaminate groundwater [2].

Utilization of agricultural waste is actually more efficient and economically profitable than the use of chemical inputs both fertilizers and pesticides. Besides the price is more expensive, scarcity and government subsidies are still lacking. Nevertheless, farmers still use inorganic fertilizers and pesticides in the hope that productivity can be higher than organic. But in fact, precisely with the use of inorganic fertilizers soil quality and quantity of results is not necessarily as expected even may decrease.

The heavy metal content is not only found in rice fields close to the industry, but there are also in paddy fields that are turning to organic development. Results of research using external inputs of site-specific chemical fertilizers still contained heavy metals in the soil (0.54-1.32 ppm) [3]. Similarly, results of research in Belgrade Serbia reported that heavy metal contaminants from the Power Plant industry had detected $\mathrm{Pb}(13.4-27.4 \mathrm{mg} / \mathrm{kg}), \mathrm{Cd}(0.11-0.27 \mathrm{mg} /$ $\mathrm{kg}), \mathrm{Cu}(20,5-34.4 \mathrm{mg} / \mathrm{kg}), \mathrm{Zn}(75.3-142 \mathrm{mg} / \mathrm{kg})$ of land on agricultural land is still below established national and international standards [4]. Based on the above consideration, it is necessary to conduct an assessment aimed at identifying heavy metal content in terraced rice field in Sruwen Village, Tengaran District, Semarang Regency.

\section{Materials And Methods}

Soil sampling was conducted in February 2017 in Sruwen Village, Tengaran District, Semarang Regency. Examples of soil are taken from each different rice field

\footnotetext{
Corresponding author: yulis_hindarwati@yahoo.co.id.
} 
height or terrace in one spreadsheet. The rice field consists of the upper rice field at an altitude of $705.9 \mathrm{~m}$ above sea level, the center at a height of $702.2 \mathrm{~m}$ asl, and the bottom at an altitude of $696.0 \mathrm{~m}$ asl. The soil is taken ten points then composited by using a soil drill (auger). Zig-zag intake at soil depth 0-20 cm and 20-40 $\mathrm{cm}$. Examples of water are taken from the main irrigation door and each canal into the compressed upper, middle, and bottom rice field. Examples of composted soil were tested to the Laboratory of Environmental Research Institute of Pati to determine the content of heavy metals $\mathrm{Pb}, \mathrm{Cd}$, and $\mathrm{Cu}$. Using the method of wet destruction in in the mixture of HNO3: $\mathrm{HClO} 4$ [5], then measured with Variance Atomic Absorption Spectrophotometer (AAS) AA240 FS Variants [6].

\section{Results And Discussion}

\subsection{The Characteristics of Location}

Semarang regency consists of 18 districts of which is District Tengaran which is located at $729 \mathrm{~m}$ above sea level. In 2015 the amount of rainfall of 3,699 $\mathrm{mm}$ with average rainfall of 1,683 $\mathrm{mm}$ in a year. Year 2014, district of Tengaran has a land area of 883.43 ha, irrigated rice field area of 652.85 ha and rain-fed rice field 230.59 ha. In 2015 the use of wetland farming area of 883.44 hectares and not rice fields $1,883.93$ ha. Area of rice harvest 1.261 .00 ha with production $6,909.02$ ton and productivity 5.48 ton/ ha [7]. Research sites with different altitudes are listed in Table 1.

The location of paddy fields from upper, middle, and lower paddy fields has different soil properties either from nutrient content or chemical residue. The presence of heavy metals in the soil is influenced by soil physical and chemical properties, such as $\mathrm{pH}, \mathrm{C}$ organic, and Cation Exchange Capacity (CEC). Assessment of soil content on land from each section is shown in table 2 .

Types of rice fields located in the village of Sruwen is grumusol with soil texture structure Silt loam. The content of soil $\mathrm{pH}$ of upper and lower rice field is neutral and somewhat acidic in middle soil. Neutral $\mathrm{pH}$ in the soil up and down is because the fields tend to be flooded continuously (flooded soil) in rice cultivation and near the water source irrigation.

Table 1. Location, coordinates, and height of rice fields in Sruwen Village

\begin{tabular}{llc}
\hline Code & \multicolumn{1}{c}{ Coordinate } & $\begin{array}{c}\text { Altitude } \\
\text { (m dpl) }\end{array}$ \\
\hline Upper rice field & $\begin{array}{l}\text { S. } 07^{\circ} 25^{\prime} 18.35^{\prime \prime} \\
\text { E. } 110^{\circ} 32^{\prime} 25.41^{\prime \prime}\end{array}$ & 696.0 \\
Middle rice field & $\begin{array}{l}\text { S. } 07^{\circ} 25^{\prime} 17.41^{\prime \prime} \\
\text { E. } 110^{\circ} 32^{\prime} 31.35^{\prime},\end{array}$ & 690.0 \\
& S. $07^{\circ} 25^{\prime} 15.75^{\prime \prime}$ & 688.0 \\
& E. $110^{\circ} 32^{\prime} 30.54^{\prime}$ & \\
\hline
\end{tabular}

Table 2. Properties of rice fields at Sruwen Village, Tengaran District, Semarang Regency

\begin{tabular}{|c|c|c|c|}
\hline Parameter & $\begin{array}{c}\text { Upper } \\
\text { Soil }\end{array}$ & $\begin{array}{c}\text { Middle } \\
\text { Soil }\end{array}$ & $\begin{array}{c}\text { Bottom } \\
\text { Soil }\end{array}$ \\
\hline \multicolumn{4}{|l|}{ Texture } \\
\hline - Sand (\%) & 23.30 & 19.13 & 22.94 \\
\hline - Silt (\%) & 58.40 & 61.58 & 53.86 \\
\hline - Clay (\%) & 18.30 & 19.30 & 23.20 \\
\hline $\mathrm{pH} \mathrm{H}_{2} \mathrm{O}$ & 6.64 & 6.21 & 6.95 \\
\hline $\mathrm{pH} \mathrm{KCl}$ & 5.28 & 4.94 & 5.52 \\
\hline C-Organic (\%) & 3.51 & 3.02 & 2.71 \\
\hline N-Kjeldahl (\%) & 0.43 & 0.33 & 0.32 \\
\hline $\mathrm{P}_{2} \mathrm{O}_{5}$ provided Olsen $(\mathrm{ppm})$ & 42.66 & 43.73 & 36.24 \\
\hline $\mathrm{P}_{2} \mathrm{O}_{5} \mathrm{HCl} 25 \%(\mathrm{mg} / 100 \mathrm{~g})$ & 128.59 & 109.45 & 105.44 \\
\hline $\mathrm{K}_{2} \mathrm{O} \mathrm{HCl} 25 \%(\mathrm{mg} / 100 \mathrm{~g})$ & 45.05 & 38.65 & 39.41 \\
\hline $\operatorname{CEC}\left(\operatorname{cmol}(+) \mathrm{kg}^{-1}\right)$ & 16.00 & 19.77 & 16.38 \\
\hline \multicolumn{4}{|l|}{$\begin{array}{l}\text { Exchangable Cation (cmol } \\
\left.(+) \mathrm{kg}^{-1}\right)\end{array}$} \\
\hline $\mathrm{K}$ & 0.04 & 0.04 & 0.04 \\
\hline $\mathrm{Na}$ & 0.05 & 0.04 & 0.04 \\
\hline $\mathrm{Ca}$ & 1.17 & 0.85 & 1.16 \\
\hline $\mathrm{Mg}$ & 0.29 & 0.20 & 0.33 \\
\hline
\end{tabular}

The content of C-organic as an indicator of organic material in the lower rice field is medium. The content of optimal soil organic matter is closely related to clay content and soil $\mathrm{pH}$. The content of $\mathrm{N}$ of the three parts of paddy soil has medium value. While the content of Phosfor (P2O5) is very high. The CEC value in upper and lower rice field is low but middle rice field is medium.

\subsection{Rice Field Management}

Farmers as the main actors in the management of rice fields and local experience until today is still the basis of farming so less attention is given to environmental sustainability. The important role of government agencies is indispensable in the management of natural resources, especially agricultural and technological innovation. The use of fertilizer and pesticides in wetland management is strongly influenced also from the economic level. Utilization of water resources that have always been available to encourage farmers to make rice fields always produce. This is as one of the triggers of farmers using inorganic fertilizers in addition to organic fertilizer.

Differences in management, land ownership, source of irrigation and the same goal that the achievement of maximum productivity impact on differences in heavy metal content on paddy fields from each farmer. Management differences are also strongly influenced by the socio-economic conditions of the farmers themselves. Economically among them is the arrangement of cropping pattern within a year. The high cost of wetland management especially in the purchase of fertilizers and pesticides has an effect on work in a year even though most farmers are not hired. The rice field located on the land refers to the cropping pattern of paddy-palawija-paddy in a year. The most commonly used fertilizer in the terraced rice terraces are inorganic fertilizers in the form of urea, phonska, and manure for rice plants. Crops are often cultivated intercropping between sweet corn and mustard, some 
are just corn. The fertilizer used is urea fertilizer, TSP and organic fertilizer in the form of manure. While organic fertilizer comes from cattle dung waste. Therefore, the amount of use of fertilizers and pesticides both organic and inorganic may be influential on the amount of heavy metal content on paddy fields.

Based on the ownership, the farmers of the upper and lower rice fields are owner farmers, while those of the middle rice field are working farmers. Differences in ownership is very influential on the success rate of farming. One of the most influencing social factors is the lack of care for the impact of land damage. Environmental sustainability factors are often unthinkable due to lack of awareness and understanding of farmers. The availability of existing water sources does not significantly affect the level of land management as it is available throughout the growing season. The presence of heavy metals in paddy fields an be derived from irrigation water flowing from the upper rice field to the rice fields below it. Other factors may also be possible from water seepage after fertilization from the upper rice field. Accumulation also can be due to the flow of water, especially the soil layer (top soil). In addition to human activities that manage the agricultural environment, the climate factor is very influential including rainfall, wind direction, humidity, sunlight. The higher the rainfall, the higher the eroded soil layer.

Location of the altitude aligned with the direction of water flow, this is one of the triggers of the increase of heavy metal content. Conservation technology which is still needed on terraced land is irrigation network improvement because it is still uneven even though the water requirement is fulfilled. Another technology that still needs to be extracted is by the exploitation of phytoremediation plants that grow a lot on any watery rice field that is still regarded as a weed by farmers. The plant is azolla that can act as a heavy metal absorber plant. Azolla is able to absorb several types of heavy metals so that it has potential aSa waste phitoabsorber containing heavy metals [8]

\subsection{The Metal Content in Soil of Rice Field}

Soil is a receptor of most of the pollutants of human activity. Degradation of soil quality can be caused by the presence of inorganic pollutants such as metals. The problem that actually needs to be explored is the monitoring of the level of environmental damage, especially in the rice fields that are quantitatively through laboratory testing. The use of excessive inorganic fertilizers in the long term as substitution of fertilizer on the soil that is used up in plant growth will accumulate. Consequently, pollution, although still below the threshold according to the standards of different heavy metal thresholds in each country. The standard and limits of heavy metal content are found in Table 3.
Table 3. Standards and Limits of Heavy Metal Content of Pb, $\mathrm{Cd}$, dan $\mathrm{Cu}$ in Soil

\begin{tabular}{lccc}
\hline \multirow{2}{*}{ Location } & \multicolumn{3}{c}{ Heavy Metal (mg/kg) } \\
\cline { 2 - 4 } & $\mathbf{P b}$ & $\mathbf{C d}$ & $\mathbf{C u}$ \\
\hline EU Standard & 300 & 3 & 140 \\
Indian Standard & $250-500$ & $3-6$ & $135-270$ \\
Normal Limit * & $2-300$ & $0,01-2,0$ & $2-250$ \\
Critical Limit * & $100-400$ & $3-8$ & $60-125$ \\
\hline
\end{tabular}

*Source: Alloway, 1995

Heavy metal is a substance that is so persistent that it can accumulate in the food chain and cause accumulated fects on humans. According to the direction of the slope or height, the upper rice field contains the highest heavy metals of both $\mathrm{Pb}, \mathrm{Cd}$, and $\mathrm{Cu}$ compared to lower paddy soils with different depths. The bigger the depth of soil, the less the content of the heavy metal.

\subsection{The Content of Heavy Metal Pb}

The heavy metal of $\mathrm{Pb}$ is found at all altitude of paddy field both at $0-20 \mathrm{~cm}$ and $20-40 \mathrm{~cm}$ depth which shows different data. The heavy metal content of $\mathrm{Pb}$ is still below the standard provisions of India (250-500 mg / $\mathrm{kg}$ ), Europe (300 mg / kg), and the critical limits in the soil are $100-400 \mathrm{mg} / \mathrm{kg}$, but fall within the normal range of 2-300 $\mathrm{mg} / \mathrm{kg}[9,10,11]$. The heavy metal content of $\mathrm{Pb}$ is possible from pesticide spraying by accumulated farmers and vehicle fumes close to the village road. The distribution of $\mathrm{Pb}$ in the soil is correlated with the depth that is decreased according to the depth caused by the formation of the $\mathrm{Pb}$ bond with the organic soil commonly found in the topsoil [2]. The contamination content of heavy metal $\mathrm{Pb}$ on the ground based on the height is shown in Figure 1.

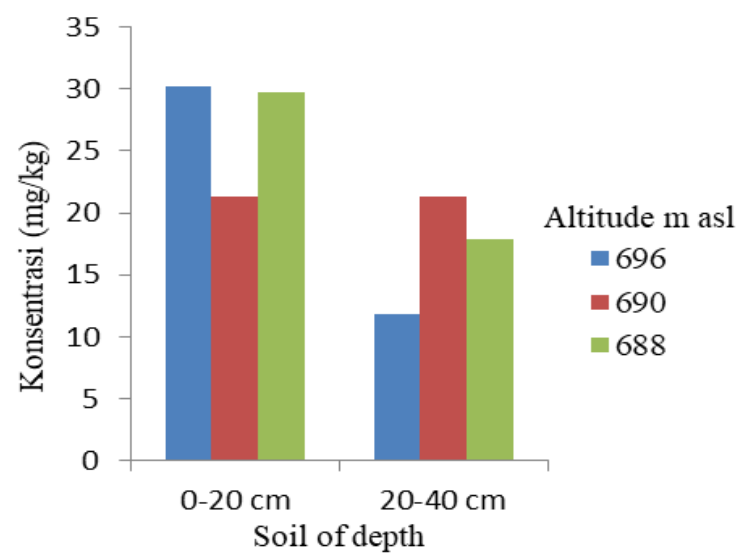

Fig 1. The content of heavy metal $\mathrm{Pb}$ at Semarang Regency 
Based on the results of testing on paddy soil with an altitude of $696,0 \mathrm{~m}$ above sea level, heavy metal content of $\mathrm{Pb}$ is higher than the height of $688,0 \mathrm{~m}$ above sea level. The content also decreases when the height decreases. This is due to the location of the upper rice fields adjacent to the river as the first irrigation source and water recipient in irrigation containing $\mathrm{Pb}$ heavy metals although similar in ownership and management of the land. The decrease in heavy metal content is correlated with the depth of soil that allows heavy metals to be absorbed in plants growing on it. While in the middle rice field is increasingly rising. The increase is possible because of differences in management such as the use of fertilizers and pesticides so that heavy metals which are generally common in the layer if they are finally dissolved in the deeper soil.

\subsection{The Content of Heavy Metal Cd}

The heavy metal Cds are present in all of the upper, middle and lower paddy fields at $0-20 \mathrm{~cm}$ and $20-40 \mathrm{~cm}$ depths which are all still below the standard of India (3$6 \mathrm{mg} / \mathrm{kg}$ ), Europe $(3 \mathrm{mg} / \mathrm{kg}$ ) And the critical limit in soil is $3-8 \mathrm{mg} / \mathrm{kg}$, but above the normal limit in soil is $0.01-2.00 \mathrm{mg} / \mathrm{kg}[9,10,11]$. Manure that is commonly used is fertilizer derived from cow dung. The presence of heavy metal content of $\mathrm{Cd}$ in the soil at all altitudes because during this time farmers still use phosphatebased chemical fertilizers is TSP and phonska fertilizers.

Fertilizer TSP that is supplied excessively in rice fields in the long term will be accumulated and cause pollution because TSP fertilizer contains heavy metals. Heavy metals are also present in natural phosphate rocks used as raw material for the manufacture of fertilizer P [12]. The addition of fertilizer will increase the concentration of $\mathrm{P}$ in the soil [2]. The presence of heavy metal content of $\mathrm{Cd}$ is also possible from the rest of the farm although the amount is not much because the phosphate compound is bound by the soil and cannot be carried away by the irrigation water flow. Another factor is possible because the application of some pesticides in the form of fungicides containing heavy metals $\mathrm{Cd}$ and $\mathrm{Cu}$. The content of contamination in the form of heavy metal $\mathrm{Cd}$ on the ground based on altitude is shown in figure 2.

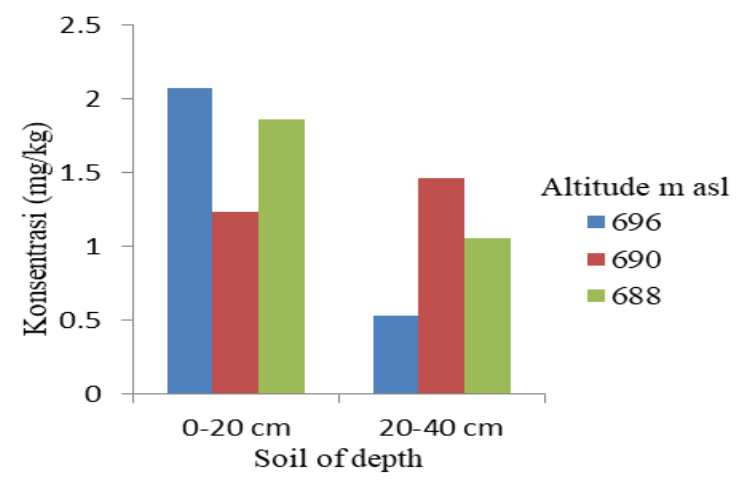

Fig 2. The Content of Heavy Metal Cd at, Semarang Regency
Variations of heavy metal content $\mathrm{Cd}$ decrease based on height and depth of soil depth in upper and lower rice field. While in the middle rice field content of $\mathrm{Cd}$ tends to increase. The high metal weight is not only from the use of chemical fertilizers and pesticides but can also be from manure containing heavy metals. Feed sources containing heavy metals will produce fertilizers containing heavy metals as well.

\subsection{The Content of Heavy Metal Cu}

Provision of chemical fertilizers supply certain nutrients in the form of high concentration of inorganic compounds and easily soluble so it can cause contamination of waterways, especially ground water if done repeatedly [13]. Higher metal content, other than the natural factor of other factors as a supplier of heavy metals in these fields is the input of fertilizer used before and during the accumulated planting. Similarly, the use of some insecticides contains heavy metals $\mathrm{Pb}$.

$\mathrm{Cu}$ heavy metals are present at all altitudes of $0-20$ $\mathrm{cm}$ and $20-40 \mathrm{~cm}$ deep, all still below the standard provisions of India (135-270 mg / kg), Europe (140 mg $/ \mathrm{kg}$ ), and the critical limits in soil are $60-125 \mathrm{mg} / \mathrm{kg}$, but still within the normal range in the soil ie $2-250 \mathrm{mg}$ $/ \mathrm{kg}[9,10,11]$. The heavy metal content of $\mathrm{Cu}$ on the soil is shown in Table 3.

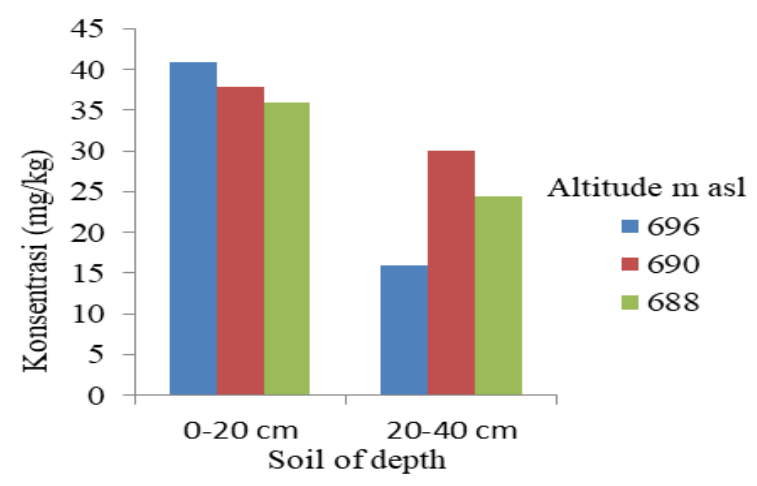

Fig 3. The Content of Heavy Metal $\mathrm{Cu}$ at Semarang Regency

$\mathrm{Cu}$ elements are present only in soils whose existence is not supported by irrigation water sources because they are undetectable based on the metal test results. One factor contributing $\mathrm{Cu}$ heavy metals to wetland is not only from pesticide applications but can be derived from natural mineral erosion events. The heavy metal content in the soil is still below the set threshold. $\mathrm{Cu}$ heavy metal content based on both height and depth is correlated. The lower the height and depth, the lower the heavy metal $\mathrm{Cu}$ content is. This can be because the metal content does not dissolve in the lower altitudes and is only found in the soil though it accumulates at $40 \mathrm{~cm}$ of soil depth. Sources of heavy metals found at the site not only from the supply of fertilizers and natural factors, but water sources that have been used in irrigation. The content of heavy metals in water is shown in table 3 . 
Table 4. The results of irrigating water testing

\begin{tabular}{lccc}
\hline \multirow{2}{*}{ Example Code } & \multicolumn{3}{c}{ Heavy Metal (ppm) } \\
& Pb & Cd & Cu \\
\hline Water irrigation & 0,0148 & nd & nd \\
Value of LoD & 0,0024 & 0,0007 & 0,0009 \\
Value of LoQ & 0,0080 & 0,0023 & 0,0030 \\
\hline
\end{tabular}

Where:

LoQ : Limit of Quantification: The lowest measurable heavy metals concentration by the $\mathrm{HClO} 4+\mathrm{HNO} 3$, AAS method).

$\mathrm{Nd}$ : Not detected or lower than the value of LoQ

LoD : Limit of Detection: The lowest measurable heavy metal concentrations measured by the instrument (AAS).

Based on the results of the irrigation water sample analysis, only the heavy metal content of $\mathrm{Pb}$ was detected. Although the water looks clear but household waste is still washed away. This is possible as one source of pollutants due to human activities in land management, especially the use of fertilizers and chemical pesticides. In addition to these effects, natural factors in the water source can be derived from a scientific weathering process [14]. The result of excessive fertilization is pollution carried by runoff into rivers [15].

Water condition is an indicator of spatial area both from the problem of the intensity of the causes of floods and droughts or the quality of which contains pollutants or sediments [16]. Use of land that is less concerned with the sustainability and health of river water can increase the pollutant content into river water bodies [17]. Related to this effort of water quality monitoring needs to be done so that the accumulative can be prevented. Management of water quality and control of water pollution to conserve water function is contained in Government Regulation of Republic of Indonesia No. 82 Year 2001. While water that can be used for agriculture purposes contained in Government Regulation No. 20 of 1990 on Water Pollution Control implemented in 1990-2001. The function of water sources that flow along the rice fields can be classified into class two, three, and four because in addition to irrigation of crops used can also in the cultivation of fisheries. Although the water source can serve to irrigate crops but in terms of water quality still contains inorganic chemical pulp that is $\mathrm{Pb}$ contamination. Heavy metal of $1 \mathrm{mg} / 1$ still under the inorganic chemical parameters of water quality criterion based on class IV as water irrigation [18]

Not all heavy metal content is present in irrigation water sources found in irrigation canals and inlet channels of each rice field. These pollutants can come from fertilizer and pesticide applications that flow from the paddy fields of water drainage. Innovative technological efforts are required to prepare irrigation systems and water resources management that meet the future economic and agricultural development needs [19]. Reducing the accumulative heavy metal residues such as the utilization of bio accumulator plants such as water hya- cinth and kiambang which are easily available on certain irrigation channels.

\section{Conclusion}

The content of heavy metal of $\mathrm{Pb}, \mathrm{Cd}$, and $\mathrm{Cu}$ on all land with different depth and altitude is still below the established threshold. The presence of heavy metal content is also because the differences in the management of rice fields. Lack of understanding of farmers makes they still apply conventional cultivation with chemical input which is not appropriate with local specific recommendation.

\section{5. suggestion}

Environmental friendly technology needs to be implemented to minimize the contamination by utilizing organic resources such as agricultural and livestock waste as well as human resources for the development and empowerment of the community for acceptable technology, and the utilization of azzola.

\section{References}

1. Y-B. Guo, H. Feng, C. Chen, C-J. Jia, F. Xiong, Y. Lu. 2013. Heavy metal concentrations in soil and agricultural products near an industrial district. Pol. J. Environ. Stud. Vol. 22, No. 5.1357-1362 (2013)

2. S. Notodarmojo. Pencemaran Tanah dan Air Tanah. Institut Teknologi Bandung. Bandung (2005)

3. Y. Hindarwati, F.D. Arianti, and H. Anwar. Identifikasi logam berat $\mathrm{Cd}$ dalam tanah dan beras di lokasi pengembangan padi organik di Kabupaten Semarang. Prosiding seminar nasional. Faperta UGM. Yogyakarta (2014)

4. Markovic, M., S. Cupac, R. Durovic, J. Milinovic, and Kljajic. Assesment of heavy metal and pesticide levels in soil and plant products from agricultural area of Belgrade, Serbia. Arch Environ Contam Toxicol 58:341-351 (2010)

5. Eviati and Sulaeman. Petunjuk Teknis Edisi 2. Analisis kimia tanah, tanaman, air, dan pupuk. Badan Penelitian dan Pengembangan Pertanian. Kementerian Pertanian (2012)

6. Varian. Analytical Methods: Flame Atomic Absorption Spectrometry. Varian Australia. Victoria (1989)

7. Badan Pusat Statistik. Kabupaten Semarang dalam angka (2016)

8. Z. Stêpniewska, R.P. Bennicelli, T.I. Balakhnina, K. Szajnocha, A. Banach, and A. Woliñska. Potential of Azolla caroliniana for the removal of $\mathrm{Pb}$ and $\mathrm{Cd}$ from wastewaters. Int. Agrophysics, 19, 251-255 (2005)

9. S.K. Awashthi. Prevention of food adulteration act no.37 of 1954 . Central and state rules as amended 
for 1999. Ashoka Law House. New Delhi. India (2000)

10. European Union. Heavy metals in wastes in wastes. European commission on environment.http://ec.europa.eu/environment/waste/studies /pdf/heavy metalsreport.pdf (2002)

11. B.J. Alloway. Heavy Metal in Soils. Blackie Academic and Profesional (1995)

12. U. Kurnia, H.Suganda, R. Saraswati, and Nurjaya. Teknologi pengendalian lahan sawah tercemar. Balai Penelitian Tanah. http://balittanah.litbang.pertanian.go.id/eng/dokum entasi/buku/tanahsawah/tanahsawah9.pdf. Accessed on 5 September 2016

13. R. Dharmawan Margolang, Jamilah, M. Sembiring. Karakteristik beberapa sifat fisik, kimia, dan biologi tanah pada sistem pertanian organik. Jurnal online agroekoteknologi. ISSN No. 2337- 6597 Vol.3, No.2 : 717 - 723 (2015)
14. R.M. Mulia. Kesehatan lingkungan. Graha Science. Jakarta (2005)

15. H.R. Mulyanto. Ilmu lingkungan. Graha Science. Jakarta (2006)

16. A. T. Sastrawijaya. Pencemaran lingkungan. Rineka Cipta. Jakarta (2009)

17. A.B. Supangat. Pengaruh berbagai penggunaan lahan terhadap kualitas air sungai di kawasan hutan pinus di Gombong, Kebumen, Jawa Tengah. Jurnal penelitian hutan dan konservasi alam.Vol. V. No. 3 : 267-276, (2008)

18. Peraturan pemerintah No. 82/2001 tentang pengelolaan kualitas air dan pengendalian pencemaran air (2001)

19. E. Pasandaran. Reformasi irigasi dalam rangka pengelolaan terpadu sumberdaya air. Analisis kebijakan pertanian. E-jurnal Litbang Pertanian. Vol. 3 No. 3, September 2005 : 217-235 (2005) 